\title{
Did the accounting for goodwill create a bubble?
}

\author{
BINGYI CHEN \\ ARIEL MARKELEVICH* \\ IRENE GUANNAN WANG \\ Suffolk University, Boston
}

\begin{abstract}
This article investigates the accounting standards changes related to business acquisitions and the impact of those changes on the reported goodwill in the past 50 years. We observe that the amount of goodwill on companies' balance sheets steadily increased before 2001 but has risen to new levels with the adoption of SFAS 141. Goodwill is now equal to about 30 percent of companies' net assets compared to only about 7 percent in the 1980s. We examine whether the increased levels of goodwill could have resulted from changes in accounting standards. Specifically, we investigate the impacts of accounting regulations on goodwill reporting under three different regimes: $A P B 16$ and 17, SFAS 141 and 142, and SFAS 141(R). We find that the increase in the reported value of goodwill is not a result of an increase in public companies' acquisitions, as those have actually decreased over time. Further, the increase overlaps with the changes to the accounting for goodwill and the switch from goodwill amortization to impairment. Our findings are timely and important because the Financial Accounting Standards Board (FASB) has a concurrent project revisiting Identifiable Intangible Assets and Subsequent Accounting for Goodwill (FASB 2020). Our evidence urges caution in the reintroduction of goodwill amortization proposed by $F A S B$, as the level of goodwill has increased dramatically despite FASB's intentions to improve the quality of goodwill accounting and curtail management's goodwill manipulation.
\end{abstract}

Keywords: Goodwill, Accounting for Goodwill, Mergers and Acquisition, Business Combinations, Regulation, FASB

Abstrak: Artikel ini menyelidiki perubahan standar akuntansi yang terkait dengan akuisisi bisnis dan dampak perubahan tersebut pada goodwill yang dilaporkan dalam 50 tahun terakhir. Kami mengamati bahwa jumlah goodwill di neraca perusahaan terus meningkat sebelum tahun 2001 tetapi telah meningkat ke tingkat yang baru dengan penerapan PSAK 141. Goodwill sekarang sama dengan sekitar 30 persen dari aset bersih perusahaan dibandingkan dengan hanya sekitar 7 persen di 1980-an. Kami memeriksa apakah peningkatan tingkat goodwill bisa dihasilkan dari perubahan standar akuntansi. Secara khusus, kami menyelidiki dampak peraturan akuntansi pada pelaporan goodwill di bawah tiga rezim yang berbeda: APB 16 dan 17, PSAK 141 dan 142, dan PSAK 141(R). Kami menemukan bahwa peningkatan nilai goodwill yang dilaporkan bukanlah hasil dari peningkatan akuisisi perusahaan publik, karena hal tersebut sebenarnya telah menurun dari waktu ke waktu. Selanjutnya, peningkatan tersebut tumpang tindih dengan perubahan akuntansi untuk goodwill dan peralihan

* Corresponding author: amarkelevich@suffolk.edu 
dari amortisasi goodwill menjadi penurunan nilai (impairment). Temuan kami tepat waktu dan penting karena Dewan Standar Akuntansi Keuangan (FASB) memiliki proyek bersamaan untuk meninjau kembali Identifiable Intangible Assets and Subsequent Accounting for Goodwill (FASB 2020). Bukti penelitian kami mendesak kehati-hatian dalam pengenalan kembali amortisasi goodwill yang diusulkan oleh FASB, karena tingkat goodwill telah meningkat secara dramatis meskipun FASB berniat untuk meningkatkan kualitas akuntansi goodwill dan mengurangi manipulasi goodwill oleh manajemen

Kata Kunci: Goodwill, Akuntansi untuk Goodwill, Merger dan Akuisisi, Kombinasi Bisnis, Regulasi, FASB

\section{Introduction}

Corporate mergers and acquisitions represent a significant business activity as companies annually spend billions of dollars to diversify and grow their operations. In 2018, there were more than 9,000 deals valued at over 800 billion completed in the U.S. alone, which is equivalent to the completion of one deal in every hour. ${ }^{1}$ When accounting for the corporate acquisition, the acquirer is required to allocate the price paid for the acquisition to the individual assets acquired and liabilities assumed, and any excess amount that has not been allocated is recorded as goodwill (APB 16). Specifically, goodwill is defined as an asset representing the future economic benefits arising from other assets acquired in a business combination that are not individually identified and separately recognized (FASB ASC 350). Presumably, the reason to pay such a premium is that the acquiring company believes it can better utilize the target's assets and create some synergies or just eliminate competition.

In this article, we investigate the potential impact of changes in accounting standards on goodwill reporting by examining the goodwill disclosed in the financial statements of U.S. public companies since the 1980s. As documented in our study, we observe that the amount of goodwill on U.S. public companies' balance sheet steadily increased over the years but has risen to new levels with the adoption of SFAS 141 in 2001. Goodwill is now equal to about 30 percent of companies' net assets relative to

\footnotetext{
${ }^{1}$ Data on corporate mergers and acquisitions was extracted from Refinitiv's Securities Data Company (SDC) Platinum database.
} 
only about 7 percent in the 1980s. We find that the increase in the reported value of goodwill is not the result of an increase in public companies' acquisitions, as those have actually decreased over time. Further, we examine if the increased levels of goodwill could be the result of changes in accounting standards. Consistent with our predictions, we find that the increase overlaps with the changes to the accounting for goodwill and the switch from goodwill amortization to impairment.

There has been a long debate on how to treat the goodwill in companies' balance sheets with two accounting approaches often argued. One approach is to treat goodwill similar to other long-lived assets and amortize goodwill over a period of time. In this case, the logic is that any potential synergies would materialize and be captured in other financial statement accounts, and the value of goodwill on the books should decrease as this occurs. Thus, as the economic benefits from goodwill are earned, the corresponding amortization expense is recorded in the income statement. The other approach is not to amortize the goodwill but only test it for impairment. Meaning, this approach suggests that potential synergies have indefinite value and should be kept on the acquirers' books forever, similar to other indefinite life intangible assets. As a precaution, the value of goodwill needs to be tested (typically annually), and if needed, the value of goodwill on the books should be decreased through an impairment loss.

Until 2001, standard setters agreed with the first approach, and accounting rules mandated that goodwill recorded at the time of the acquisition should be amortized over up to 40 years. However, with the adoption of SFAS 141 in 2001, the second approach was implemented, and goodwill is no longer amortized but rather only tested for impairment.

To examine the significant increase in goodwill recorded on companies' balance sheets, we begin by reviewing the level of corporate acquisitions over time. Next, we review the goodwill accounting standards issued by the FASB for the last fifty years. We finally examine goodwill on companies' balance sheets and how the changes in goodwill accounting potentially impacted the asset levels.

This study makes two main contributions. First, it investigates the impact of accounting regulations on the goodwill reporting under three different regimes: APB 16 
and 17, SFAS 141 and 142, and SFAS 141(R). Unlike prior studies that emphasize the adoption of a specific regulation, this study tracks the regulation changes and portrays the corresponding consequences on goodwill over the long run. Second, this study informs accounting standard setters and other stakeholders of potential shifts in firms' reported goodwill due to changes in goodwill regulations. This study is timely and important because the Financial Accounting Standards Board (FASB) has a concurrent project revisiting Identifiable Intangible Assets and Subsequent Accounting for Goodwill (FASB 2020). Our evidence suggests that goodwill surges overtimes, despite FASB's intentions to improve the quality of goodwill accounting and curtail management's goodwill manipulation. Our findings inform standard setters by providing ex-post evidence on how standard-setting decisions affect financial reporting. As the FASB considers changes to the accounting for goodwill, they should be informed by the findings of this study and the potential implications of their choices. This study has both ex-post and ex-ante values to standard setters. As said by Barth (2018), what was ex-post for the prior goodwill accounting rules, was ex-ante for "Identifiable Intangible Assets and Subsequent Accounting for Goodwill" that are currently being revisited (FASB, 2020). Our findings urge caution in the reintroduction of goodwill amortization proposed by FASB, as amortizing the cost of goodwill on arbitrary bases may introduce excessive leniency and encourage opportunistic behaviors.

\section{Research Design}

This study investigates the accounting standards changes related to business acquisitions and the impact of those changes on the reported goodwill. We start by reviewing the different accounting rules on the reporting of goodwill since 1970, including APB 16 and 17, SFAS 141 and 142, and SFAS 141(R). We include all U.S. public companies between 1982 to 2019 with goodwill data from Compustat to examine the value of reported goodwill over time. Additionally, to examine the corporate acquisition activity over time, we include all completed mergers of non-financial U.S. public companies between 1991 and 2018 with deal data from the Securities Data Company (SDC) Platinum. 


\section{Research Background - Corporate Acquisition Activity Over Time}

Corporate acquisitions continue to be an important business activity, with annual deal values reaching $\$ 800$ billion. The number of corporate acquisition deals has shown several waves over the last few decades. However, interestingly enough, in the last twenty years or so, the number of corporate acquisitions completed by public company acquirers has steadily decreased. In contrast, the activity by private acquirers has increased. The increase in the acquisitions by private companies has been driven primarily by private equity firms (Institutional Investor, 2006).

Chart 1.

Corporate Acquisition Activity Over Time

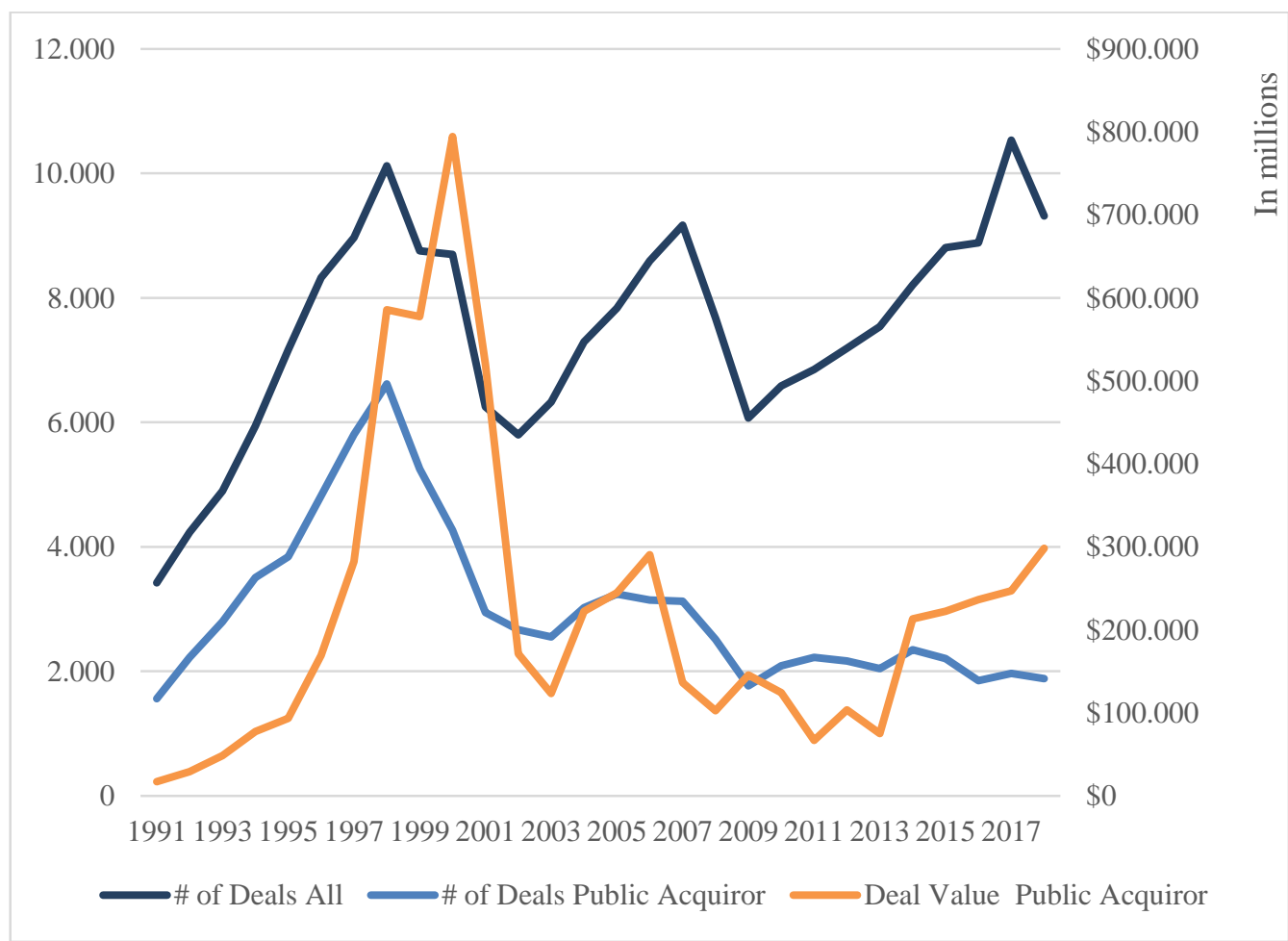

Source: Refinitiv's SDC database

As depicted in Chart 1, the total number of completed acquisitions shows waves, with peeks in 1998, 2007, and 2017. However, the number of deals completed by public company acquirers peeked in 1998 but has since decreased. The value of public company deals follows a similar decreasing pattern as the volume of acquisitions over 
the same period. Given the decreasing trend of the volume and amount of public company acquisitions, we expect the amount of goodwill carried on public companies' balance sheets to decrease similarly. However, this is not the case, as we see later in the subsequent analysis. We later review goodwill accounting standards to consider if changes in goodwill accounting can help explain this unexpected finding.

\section{Theoretical Development}

\subsection{Goodwill literature}

APB 16 introduced pooling and purchase methods into the reporting of the business combination. Although there are not many quantitative studies on the effectiveness of the regulation, some research conducted interviews or qualitative studies on this issue and documented the shift of firms' accounting choices after the adoption of APB 16 in the '70s (e.g., Libby, 1972; Davis, 1991). Libby (1972) documents a shift from pooling to purchase methods and significant changes in provisions. Davis (1991) tracks the changes in business practice from 1970 to 1990 and argues that APB 16 became less effective due to the business environment change.

SFAS 141 and SFAS 142 became effective after June 30, 2001. SFAS 141 replaced the pooling-of-interests method with the purchase method, while SFAS 142 eliminated goodwill amortization. The combined effect of these two new standards introduced changes to several aspects of the measurement and recognition for goodwill. Several studies have assessed whether the changes introduced by SFAS 141 and SFAS 142 improved the reliability of the goodwill number and strengthened goodwill's predictive power on future performance. The evidence is mixed.

A few studies have provided supportive evidence on the effectiveness of SFAS 141 and 142, and 141(R) (Chen, Kohlbeck, and Warfield, 2008; Olante, 2013; Lys and Yehuda, 2019; Kwon and Wang, 2021). For instance, Chen, Kohlbeck, and Warfield (2008) report increased value relevance associated with the adoption of SFAS 142. Their study analyzed goodwill write-offs recognized in the year of transition from APB 16-17 to SFAS 142 and found that SFAS 142 provisions resulted in more timely recognition of goodwill impairment losses. Watts (2003a) and Watts (2003b) examine 
the impact of the new standards on the accounting conservatism and find the new standards introduced unverifiable estimations to the accounting system. Olante (2013) finds that SFAS 142 improved the ability of accounting standards to detect bloated goodwill and situations in which the amount of goodwill should be written down. Lys and Yehuda (2019) find that recognized goodwill is a better predictor of future operating performance. Chen, Kohlbeck, and Warfield (2008) investigate the timeliness and value relevance of the reported goodwill and goodwill impairments after the adoption of SFAS 142. Their findings suggest that goodwill impairment represented new information to the market after adopting SFAS 142, and the value relevance of goodwill is also improved accordingly. Kwon and Wang (2021) find a positive, albeit weak, relationship between the value relevance is goodwill and the adoption of SFAS 141(R).

In the meantime, some studies have criticized the adoption of SFAS 141 and 142. For example, a few studies argue that these new standards introduced unverifiable estimations to the accounting system and gave the management more opportunities for delaying or understating goodwill impairments (Watts, 2003a; Watts,2003b; Hayn and Hughes, 2006). Other studies also find that, in the post-SFAS 141 and-142 regimes, management has incentives to delay the recognition of goodwill impairment to boost personal compensations or opportunistically manipulate financial reports by timing the goodwill write-offs (Beatty and Weber, 2006; Hayn and Hughes, 2006; Ramanna and Watts, 2012). For instance, Hayn and Hughes (2006) find that available disclosures do not adequately provide financial statement users with information to predict future goodwill write-offs. Similarly, Ramanna and Watts (2012) find evidence that managers will, on average, use the unverifiable discretion in SFAS 142 consistent with private incentives.

Unlike prior studies that emphasize the adoption of a specific regulation, this study tracks the regulation changes and portraits the correspondent consequences on goodwill over the long run. We examine the reported goodwill changes over three different regimes: APB 16 and 17, SFAS 141 and 142, and SFAS 141(R). 


\subsection{Expectations for the impact of the changes in the reporting of goodwill}

Starting with the issuance of APB 16 in 1970, we review the different accounting standards in the last 50 years used to account for business combinations and examine the potential ways these standards could have affected the value of goodwill recorded on public companies' balance sheets. A summary of our review is presented in Table 1 below.

$A P B 16$

APB opinion No. 16 Business Combinations was issued in August 1970 and became effective for all business combinations initiated after October 31, 1970. The standard established two methods to account for business combinations: the pooling of interest and purchase methods. Specifically, the statement said, "The cost to an acquiring corporation of an entire acquired company should be determined by the principles of accounting for the acquisition of an asset. That cost should then be allocated to the identifiable individual assets acquired, and liabilities assumed based on their fair values; the unallocated cost should be recorded as goodwill." (APB 16, paragraph 8). Further, goodwill had to be amortized in accordance with APB Opinion No. 17 Intangible Assets, meaning amortized for no longer than 40 years. SFAS 141

SFAS 141 was issued in June 2001 and became effective for all business combinations initiated after June 30, 2001. The statement was codified in Topic 805 Business Combination. The statement's purpose was to address financial accounting and reporting for business combinations and supersede APB 16 and FASB Statement No. 38, Accounting for Pre-acquisition Contingencies of Purchased Enterprises. FASB believed that SFAS 141 improved the transparency of business combination reporting by (1) eliminating the pooling method and allowing for only the purchase method which records a business combination based on the values exchanged; (2) improving the comparability of reported financial information; and 3) providing explicit criteria for recognition of intangible assets apart from goodwill and the expanded disclosure requirements regarding the assets acquired and liabilities assumed in the business combinations (FASB 2001a). The purchase method reports the acquired assets and 
liabilities at fair value. Therefore, the net value of acquired assets was likely to increase compared to the pooling method, while the excess of consideration transferred, which is the goodwill, was likely to decrease.

\section{SFAS 142}

SFAS 142, Goodwill and Other Intangible Assets was also issued in June 2001 and was effective for calendar year companies on January 31, 2002. SFAS 142 superseded APB 17 and fundamentally changed the treatment for goodwill. After their initial recognition, the standard took a very different approach to how goodwill and other intangible assets were accounted for (FASB 2001b). The statement was codified in Topic 350 Intangibles-Goodwill and Other.

SFAS 142 eliminated the amortization process of intangible assets with indefinite lives. Instead, goodwill and intangible assets that have indefinite useful lives will be tested at least annually for possible impairment. SFAS 142 also provided specific guidance for testing goodwill for impairment in a two-step process. The first step is screening for potential impairment, and the second step measures the amount of impairment by comparing the fair values of those assets with their recorded amounts. Intangible assets that have finite useful lives will continue to be amortized over their useful lives.

Therefore, the impairment process introduced by SFAS 142 likely increased the value of goodwill recorded on the balance sheet for two reasons. First, since goodwill is no longer periodically amortized, the goodwill amount would not decrease systematically. Second, the impairment process is subject to management discretion. SFAS 142 may open the door for manipulation in the timing and amount of recognizing impairment loss. It may allow management to delay the recognition of the impairment and impair a lower amount.

SFAS 141(R)

The Financial Accounting Standards Board issued SFAS 141(R) in December 2007 to replace SFAS 141. SFAS 141R introduced the acquisition method and kept the main requirements as in the purchase method. Moreover, SFAS 141R extended its scope to all business combinations while SFAS 141 only applied to business combinations in 
which the acquirers obtained control. FASB believed that by applying the same rules on all transactions, SFAS 141R "improves the comparability of the information about business combinations provided in financial reports" (FASB 2007). The statement revised the codification of Topic 805 Business Combination.

\section{Transaction cost}

The acquisition costs were included in the purchase price of the transaction under SFAS141. In other words, the acquisition cost was considered as an "asset" by the acquirer company after the deal. FASB recognized that such acquisition costs do not necessarily have the profit-generating ability, and therefore recognizing it as a longterm asset would overstate the acquirer's total asset. Thus, SFAS 141(R) required that the transaction cost should not be included in goodwill and must be expensed as incurred.

\section{Goodwill and Non-Controlling Interest}

SFAS 141(R) changed the accounting treatments for acquisitions in which the acquirer purchases less than $100 \%$ of the target. Prior to SFAS 141(R), goodwill was measured as the excess of investment cost over the acquirer's proportionate share of net identifiable assets. FASB believes that the old standard does not fully represent the value of the non-controlling interest. After SFAS 141(R), goodwill is calculated as the excess of the consideration transferred plus the fair value of any non-controlling interest over the fair values of net identifiable assets. In other words, the reported goodwill does not only represent the synergies acquired by the acquirer but also represents the economic benefits of the component that was not acquired. Therefore, the magnitude of the goodwill is likely to increase after the adoption of SFAS 141(R).

Overall, we expect the net effect of the accounting changes has led to a higher reported goodwill balance. Under current rules, we are relying on management's assessment of the goodwill. Current rules are also costly because determining the need for the assessment is complex and highly subjective, which requires expertise, time, and money. 
Table 1.

The Impacts of Regulation Changes on the Reporting of Goodwill

\begin{tabular}{|c|c|c|c|c|c|}
\hline Item affected & APB 16 and 17 & SFAS 141 & SFAS 142 & SFAS 141(R) & $\begin{array}{l}\text { Expected impact on the } \\
\text { magnitude of goodwill } \\
\text { from accounting } \\
\text { change }\end{array}$ \\
\hline $\begin{array}{l}\text { Valuation } \\
\text { Method }\end{array}$ & $\begin{array}{l}\text { Pooling method } \\
\text { Purchase method }\end{array}$ & Purchase method & & & Decrease \\
\hline $\begin{array}{l}\text { Goodwill } \\
\text { Amortization }\end{array}$ & $\begin{array}{l}\text { Goodwill is } \\
\text { amortized for no } \\
\text { longer than } 40 \text { years. }\end{array}$ & & $\begin{array}{l}\text { Goodwill } \\
\text { amortization is } \\
\text { eliminated. Firms } \\
\text { are required to } \\
\text { perform an } \\
\text { evaluation of } \\
\text { impairment losses at } \\
\text { least annually. }\end{array}$ & & Increase \\
\hline $\begin{array}{l}\text { Transaction } \\
\text { Cost }\end{array}$ & & $\begin{array}{l}\text { The transaction costs } \\
\text { are capitalized as } \\
\text { acquired assets. }\end{array}$ & & $\begin{array}{l}\text { The transaction costs } \\
\text { should not be included } \\
\text { in goodwill and must } \\
\text { be expensed as } \\
\text { incurred. }\end{array}$ & Decrease \\
\hline $\begin{array}{l}\text { Goodwill and } \\
\text { Non-Controlling } \\
\text { Interest }\end{array}$ & & $\begin{array}{l}\text { Goodwill is measured } \\
\text { as the excess of } \\
\text { investment cost over } \\
\text { the acquirer's } \\
\text { proportionate share of } \\
\text { net identifiable assets. }\end{array}$ & & $\begin{array}{l}\text { Goodwill is calculated } \\
\text { as the excess of the } \\
\text { consideration } \\
\text { transferred plus the } \\
\text { fair value of any non- } \\
\text { controlling interest } \\
\text { over the fair values of } \\
\text { net identifiable assets. }\end{array}$ & Increase \\
\hline
\end{tabular}




\section{Result}

We next examine the levels of goodwill on companies' balance sheets. ${ }^{2}$ We sum the goodwill on the balance sheet of all U.S. public companies and divide it by either the sum of total assets or the sum of stockholder's equity. These measures represent how significant is goodwill's share of the companies' assets and its share of the net value of the companies.

As can be seen in Chart 2, goodwill as a percentage of assets and equity has steadily increased over time. ${ }^{3}$ We observe an increase in the late 1990s, likely resulting from the increase in merger and acquisition activity. However, this increase continues, although the number of deals decreases significantly. When examining goodwill as a percentage of total assets, we see a steady increase over time, reaching about 5 percent. This suggests that goodwill comprises a significant portion of companies' assets. It is worth noting that this is just goodwill and not all intangible assets. When studying goodwill as a percentage of equity (net assets), we also observe a steady increase over time; however, the increase is much steeper than what we saw before. In addition, we observe a significant increase in the levels of goodwill as a percentage of equity (net assets) in 2002. 2002 is when SFAS 141 and 142 became effective. Although causation cannot be determined, the change in the accounting for goodwill seems to be associated with a significant increase in goodwill.

In recent years, goodwill has been anywhere between a fourth and a third of companies' net assets. Beyond the mere significance of the amount, since goodwill is subject to annual impairment tests, the potential impact of significant impairment to goodwill on the companies' book value could be devastating. For instance, in the third quarter of 2018 , G.E. took a $\$ 22$ billion goodwill impairment loss. ${ }^{4}$ to record a $\$ 22.8$ billion loss.

\footnotetext{
${ }^{2}$ Financial accounting data was extracted from Compustat.

${ }^{3} \mathrm{We}$ start the chart in the 1980s because the levels of goodwill in 1970 were low. ${ }^{4}$ https://www.wsj.com/articles/ges-22-billion-charge-intensifies-regulatory-scrutiny1540942603
} 
Impairments to goodwill would have a significant impact on companies' income in future years. Moreover, the idiosyncratic nature of the impairments could also introduce significant volatility to the income.

Chart 2.

Goodwill Over Time



Sources: Compustat and Refinitiv's SDC database

\section{Concluding Thoughts}

The reported value of goodwill has increased on companies' balance sheets over time both as a percentage of the companies' assets as well as a percentage of the companies' net assets. This increase has been steady but has been much more significant post the adoption of SFAS 141 and 142 in 2002. This increase is not a result of an increase in public companies' acquisitions, as those have actually decreased over time. The increase overlaps with the changes to the accounting for goodwill and the switch from goodwill amortization to impairment. These high levels of goodwill may represent 
a vulnerability on companies' balance sheets as a potential impairment to goodwill can significantly impact companies' total assets and net assets.

The FASB embarked on a project to examine the accounting for goodwill and may be considering a return to amortizing goodwill over time. We commend this move by the FASB as it will hopefully curtail the increase in the levels of goodwill, thus reducing the potential vulnerability.

One limitation of our study is that we focus on the association between the changes in the level of goodwill and the changes in how goodwill is accounted for. We cannot determine causality and whether the observed changes in the goodwill level were caused by the changes in the accounting for goodwill. In addition, our study is limited to the changes in the accounting for goodwill in the U.S. and the changes it may have caused in the level of goodwill. Future research could examine similar changes in the accounting for goodwill in other countries, whether it was amortized or only checked for impairment, and see whether those changes impacted the levels of goodwill.

\section{Reference}

Accounting Principles Board. 1970. APB 16 Business Combinations. Available at: https://www.fasb.org/cs/BlobServer?blobkey=id\&blobnocache=true\&blobwhere $=1175820194$ 221\&blobheader=application \%2Fpdf\&blobheadername2=ContentLength\&blobheadername1=ContentDisposition\&blobheadervalue2=118985\&blobheadervalue1=filename\%3Dapb16.pd $\underline{\mathrm{f} \& \text { blobcol}=\text { urldata } \& \text { blobtable }=\text { MungoBlobs }}$

Accounting Principles Board. 1970. APB 17 Intangible Assets. Available at: http://www.fasb.org/cs/BlobServer?blobkey=id\&blobnocache=true \&blobwhere $=11758201952$ $\underline{41 \& \text { blobheader }=\text { application/pdf\&blobcol=urldata\&blobtable }=\text { MungoBlobs }}$

Barth, M.E. 2018. How International Accounting Research Influences Policy and Standard Setting. Journal of International Accounting Research, 17 (2): 1-11.

Beatty, A., and J. Weber, 2006, Accounting discretion in fair value estimates: An examination of SFAS 142 goodwill impairments. Journal of Accounting Research, 44 (2) pp. 257 288

Chen, C., Kohlbeck, M., \& Warfield, T. 2008. Timeliness of impairment recognition: Evidence from the initial adoption of SFAS 142. Advances in Accounting, 24(1): 72-81. 
Davis, M, 1991, APB 16: Time to Reconsider. Journal of Accountancy, 172 (4):99-103.

Financial Accounting Standards Board. 2001a. Statement of Financial Accounting Standards No. 141 Business Combinations. Available at: https://www.fasb.org/summary/stsum141.shtml

Financial Accounting Standards Board. 2001b. Statement of Financial Accounting Standards No. 142 Goodwill and Other Intangible Assets. Available at: https://www.fasb.org/summary/stsum142.shtml

Financial Accounting Standards Board. 2007. Statement of Financial Accounting Standards No. 141 (revised 2007) Business Combinations. Available at: https://www.fasb.org/pdf/fas141r.pdf

Financial Accounting Standards Board. 2020 Project update Identifiable Intangible Assets and Subsequent Accounting for Goodwill. Available at:

https://www.fasb.org/jsp/FASB/FASBContent_C/ProjectUpdateExpandPage\&cid=117617156 6054\&pf=true

Financial Accounting Standards Board. Accounting Standard Codification, paragraph 350-2020.

Hayn, C., and P.J. Hughes, 2006, Leading indicators of goodwill impairment. Journal of Accounting, Auditing \& Finance, 21, pp. 223-265.

Institutional Investor. 2006. Private Equity Nabs Bigger M\&A Share. Available at: https://www.institutionalinvestor.com/article/b150nx00qwx4n3/private-equity-nabsbigger-ma-share

Kwon, S. H. and G. Wang. 2020. The change in the value relevance of accounting information after mergers and acquisitions: evidence from the adoption of SFAS 141(R). Accounting and Finance, 20 (3): 2717-2757.

Libby, R, 1972, The early impact of APB Opinions No. 16 and 17-- An empirical study. The CPA Journal, 42 (10), pp. 827-841.

Lys, T., Vincent, L., and N. Yehuda. 2017. The Nature and Implications of Acquisition Goodwill. Asia-Pacific Journal of Accounting \& Economics, 26(6): 709-730.

Olante, M. E. Overpaid acquisitions and goodwill impairment losses - Evidence from the U.S. Advances in Accounting, 29(2), December 2013, Pages 243-254

Ramanna, K., R.L. Watts, 2012, evidence from goodwill non-impairments on the effects of unverifiable fair-value accounting. Review of Accounting Studies, 17, 749-780.

Watts, R. L., 2003, Conservatism in accounting part I: Explanations and implications. Accounting Horizons, 17(3) (2003), pp. 207-221. 
The Indonesian Journal of Accounting Research - Sept, Vol. 24, No.3, 2021

Watts, R. L., 2003, Conservatism in accounting part II: Evidence and research opportunities. Accounting Horizons, 17 (4) (2003), pp. 287-301. 